\title{
SEM and 3D microtomography application to investigate the distribution of fibers in advanced cementitious composites
}

\section{Aplicação de MEV e microtomografia 3D na investigação da distribuição de fibras em compósitos cimentícios avançados}

A. M. GIL a augustomg@unisinos.br

B.F. TUTIKIAN a bftutikian@unisinos.br

\begin{abstract}
The incorporation of fibers on cement composites reduces its fragility, turning it a ductile material. The amount of fibers and its distribution presents a large influence on the composite performance, especially by the fact that it is self-consolidating, which facilitates the fiber distribution. 3D microtomography is an efficient tool for determining the fibers distribution, generating images and creating a representation in three dimensions of the sample. Moreover, the scanning electron microscopy (SEM) can be used to analyze the interaction of fibers with the cement composite. The purpose of this paper is to investigate the application of these techniques to visualize the distribution and interaction of metallic and polypropylene fibers inserted into an advanced cementitious composite, at $3 \%$ in volume content. The results presented these techniques' efficiency in the verification of fibers distribution within the mixture and the absence of flaws in the composition.
\end{abstract}

Keywords: advanced composites, fibers, microtomography, scanning electron microscopy.

\section{Resumo}

A incorporação de fibras em compostos cimentícios atenua sua fragilidade, tornando-o um material dúctil. A quantidade e dispersão das fibras exercem grande influência em seu desempenho. O compósito cimentício avançado é autoadensável, o que facilita a distribuição das fibras. A microtomografia 3D é uma ferramenta eficiente para determinação do posicionamento das fibras, gerando imagens sequencialmente, criando uma representação em três dimensões da amostra. Ainda, a microscopia eletrônica de varredura (MEV) pode ser utilizada na análise da interação das fibras com o compósito. O objetivo deste artigo é investigar a aplicação destas técnicas para visualizar a distribuição e a interação de fibras metálicas e de polipropileno inseridas em um compósito cimentício avançado, em teor de $3 \%$ em volume. Os resultados comprovaram a eficiência dos métodos, sendo possível verificar a distribuição das fibras dentro da mistura e a inexistência de falhas na composição.

Palavras-chave: compósitos avançados, fibras, microtomografia, microscopia eletrônica de varredura.

Instituto Tecnológico em Desempenho e Construção Civil, PPGEC, Unisinos, São Leopoldo, RS, Brasil. 


\section{Introduction}

The development of advanced cementitious composites aims to achieve the properties unreached with the use of conventional materials. Therefore, conventional concrete composition, mix design methods, raw materials and its cure are modified. Li [1] emphasizes the growth of such advanced composite's use and improvement, exceeding the academic and laboratory barriers, presenting viability for commercial and large-scale applications.

The interest in the application of such materials lies on its aptitude for special cases by its high potential of durability, loadbearing capacity and structure's low weight due to lower sections necessary to withstand the imposed loads [2]. Blais and Couture [3] stands out that, under the same conditions of plane geometry and load, there is a $50 \%$ reduction in the depth required for structures using advanced cementitious composites when compared to conventional concrete, as shown in Table 1.

Unlike conventional concrete, used since 1907 [4], advanced cementitious composites have recent use in the world and requires greater knowledge of its properties, microstructure, and characteristics. Then, its application depends on the development of studies to provide the knowledge necessary to perform the correct diagnose and evaluation. One of the main current study approach is the fiber incorporation into cementitious composites in its variety of kinds of materials and geometry.

Neville and Brooks [5] classify fibers as discontinuous and discrete, mentioning other possibilities of material's composition such as cellulose, steel and carbon. Complementarily the authors stand out the innumerous benefits of using such materials, since there is proper interfacial adhesion, dependent on fiber's surface roughness.

The incorporation of randomly distributed microfiber changes composites mechanical properties, through cracks initiation and propagation control, leading to greater ductility [6]. The fiber hybridization consists in the use of two or more fiber type in cementitious composites, which has shown as an efficient solution to increase material's tensile strength and reduction of crack's propagation. The use of fibers with different materials and dimensions provides greater synergy to the composite, once each fiber type acts in different times during the loading process. The hybrid fiber mix provides benefits in composite's tensile strength, cracks control and ductility increase $[7,8]$. However, in order to obtain these properties it is required fiber's even distribution.
Papers $[9,10,11,12]$ demonstrate the viability of using advanced tests to obtain images for the diagnosis of microstructural damage in concrete specimens. One method to visualize the fiber distribution consists in the microscopic diagnose by the use of specific equipment. One of the tools for determining the distribution of fibers within advanced cementitious composites is the high-resolution 3D microtomography $[12,13]$. This method proposes the graphical display and presentation of the different components of the same mixture by the density difference between its components. The use of microtomography technique aim to identify the proportion and arrangement of different types of fibers, which is guaranteed by distinct material's $\mathrm{x}$-ray absorption, which enables a contrast in the image's reproduction [13].

Another major factor is the verification of fibers' interaction with the cementitious composite, its influence to the creation of transition regions and the interface between different materials. This interaction can be assessed by scanning electron microscopy (SEM), which generates images that allow the visualization of the interface between two materials. The adhesion of the composite fibers is the main feature that influence the desired performance and depends on the material that comprises the fibers.

Landis et al. [10] used the image capture as the method of quantitation and analysis of damage in concrete specimens, concluding that this is an effective tool for this use. Maroliya [14] generated SEM images using $35 x$ and $1000 x$ approximations in a composite containing 0,20 of steel fibers relative to the weight of cement, standing the possibility of transition zone identification. According to the author, images presented material's compact interface, with complete envelopment of steel fibers by the cementitious matrix. Yazici et al. [15] obtained the same verification, recognizing the interface area between the fibers and the cementitious matrix as dense and compact. Henry, Darma and Sugiyama [16] used the 3D microtomography technique to analyze the effects of thermal curing and reheat in high performance concrete samples. According to the authors, this method allowed the verification of the water/cement reduction effect in advanced composites due to the reduction of void's presence. Within this context, this paper aimed to investigate the application of 3D microtomography and SEM techniques to analyze the distribution and interaction of fiber hybrid mixture of steel and polypropylene fibers inserted in an advanced cementitious composite.

\section{Table 1 - Section depth and weight comparison of different construction systems}

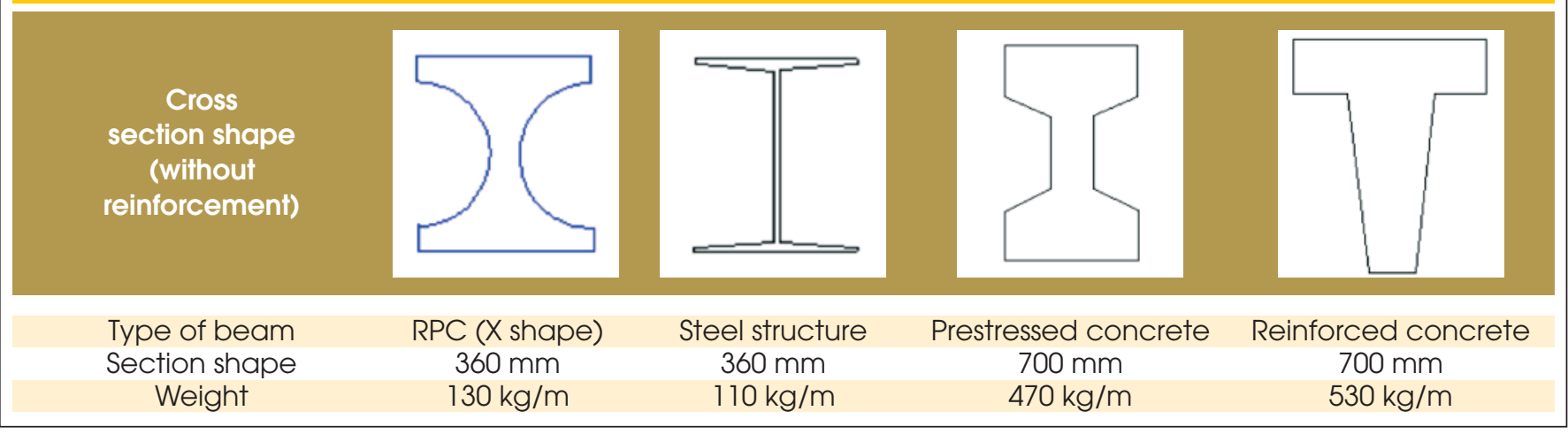


SEM and 3D microtomography application to investigate the distribution of fibers in advanced cementitious composites

Table 2 - Physical and chemical characteristics of the binders

\begin{tabular}{|cccc|}
\hline Components & Cement & Silica & Fly ash \\
\hline $\mathrm{CaO}(\%)$ & 63,19 & 0,29 & 0,9 \\
$\mathrm{SiO}_{2}(\%)$ & 19,53 & 88,43 & 69,3 \\
$\mathrm{Al}_{2} \mathrm{O}_{3}(\%)$ & 3,91 & 0,32 & 26,1 \\
$\mathrm{SO}_{3}(\%)$ & 3,07 & - & - \\
$\mathrm{Fe}_{2} \mathrm{O}_{3}(\%)$ & 2,89 & 0,01 & 1,8 \\
$\mathrm{MgO}(\%)$ & 1,94 & 0,12 & 0,05 \\
$\mathrm{~K}_{2} \mathrm{O}(\%)$ & 0,61 & 0,66 & 1,4 \\
$\mathrm{Na} 2 \mathrm{O}(\%)$ & 0,04 & 2,79 & 0,3 \\
Loss on Ignition (LI) & 3,76 & - & - \\
$\mathrm{C}_{3} \mathrm{~S}(\%)$ & 78,37 & - & - \\
$\mathrm{C}_{3} \mathrm{~A}(\%)$ & 5,47 & - & - \\
$\mathrm{C}_{4} \mathrm{AF}(\%)$ & 8,79 & - & - \\
Specific mass (gm/ $\left./ \mathrm{cm}^{3}\right)$ & 3,09 & 2,35 & 2,97 \\
Specific surface $\left(\mathrm{cm}^{2} / \mathrm{g}\right)$ & 4190 & 200000 & 3890 \\
\hline
\end{tabular}

\section{Materials e experimental program}

In order to analyze the feasibility of 3D microtomography and SEM techniques application cylindrical samples taken from a prismatic specimen were used, according to experimental program following described.

\subsection{Materials}

The binders used were Portland cement with a few additions of

\section{Table 3 - Aggregate's particle size distribution}

\begin{tabular}{|c|c|c|c|}
\hline Size $(\mu \mathrm{m})$ & $\begin{array}{c}\text { Powder } \\
\text { Retained } \\
(\%)\end{array}$ & $\begin{array}{c}\text { Sand 1 } \\
\text { Retained } \\
(\%)\end{array}$ & $\begin{array}{c}\text { Sand 2 } \\
\text { Retained } \\
(\%)\end{array}$ \\
\hline 4000 & 0 & 0,07 & 0 \\
2000 & 0 & 0,03 & 0 \\
703,9 & 0 & 0,3 & 7,7 \\
352 & 0 & 1,6 & 13,4 \\
209,3 & 0 & 2,4 & 3,6 \\
148 & 0,4 & 25,0 & 0,9 \\
104,6 & 0,7 & 17,7 & 0,7 \\
73,99 & 1,7 & 0,8 & 0 \\
44 & 6,4 & 0 & 0 \\
22 & 10,0 & 0 & 0 \\
11 & 2,8 & 0 & 0 \\
5,5 & 1,8 & 0 & 0 \\
1,944 & 1,2 & 0 & 0 \\
0,817 & 0,6 & 0 & 0 \\
\hline
\end{tabular}

silica fume and fly ash. Physical and chemical characterization of these materials are presented in Table 2. Two fine aggregates and an origin quartz powder with spherical grains and without organic material were used. The particle size distribution of these materials is presented in Table 3.

The particle size distribution of the used materials in this experimental program is presented in Figure 01 and Figure 02, to the powders and fine aggregates, respectively. A software was used to determine the amount of each material necessary to

\section{Figure 1 - Cement, silica fume, fly ash and quartz powder particle size distribution}

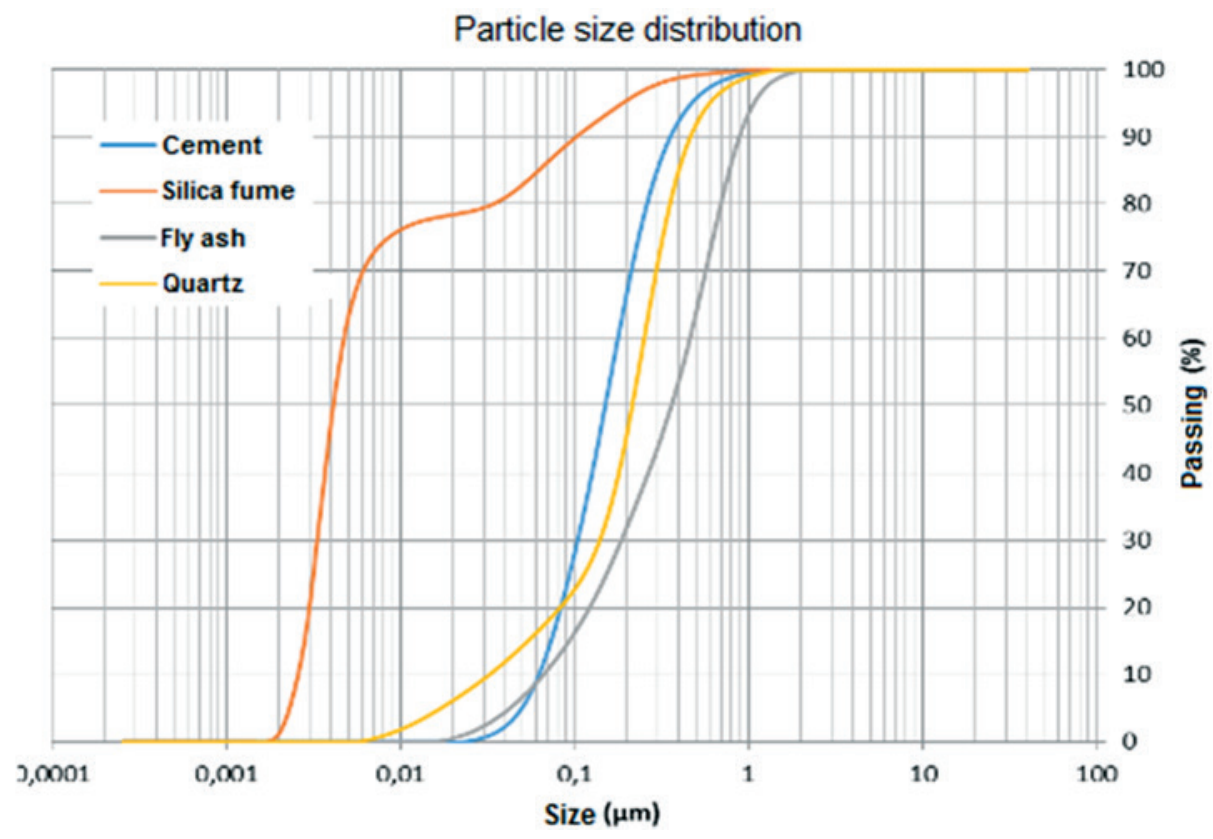


Figure 2 - Sand's particle size distribution

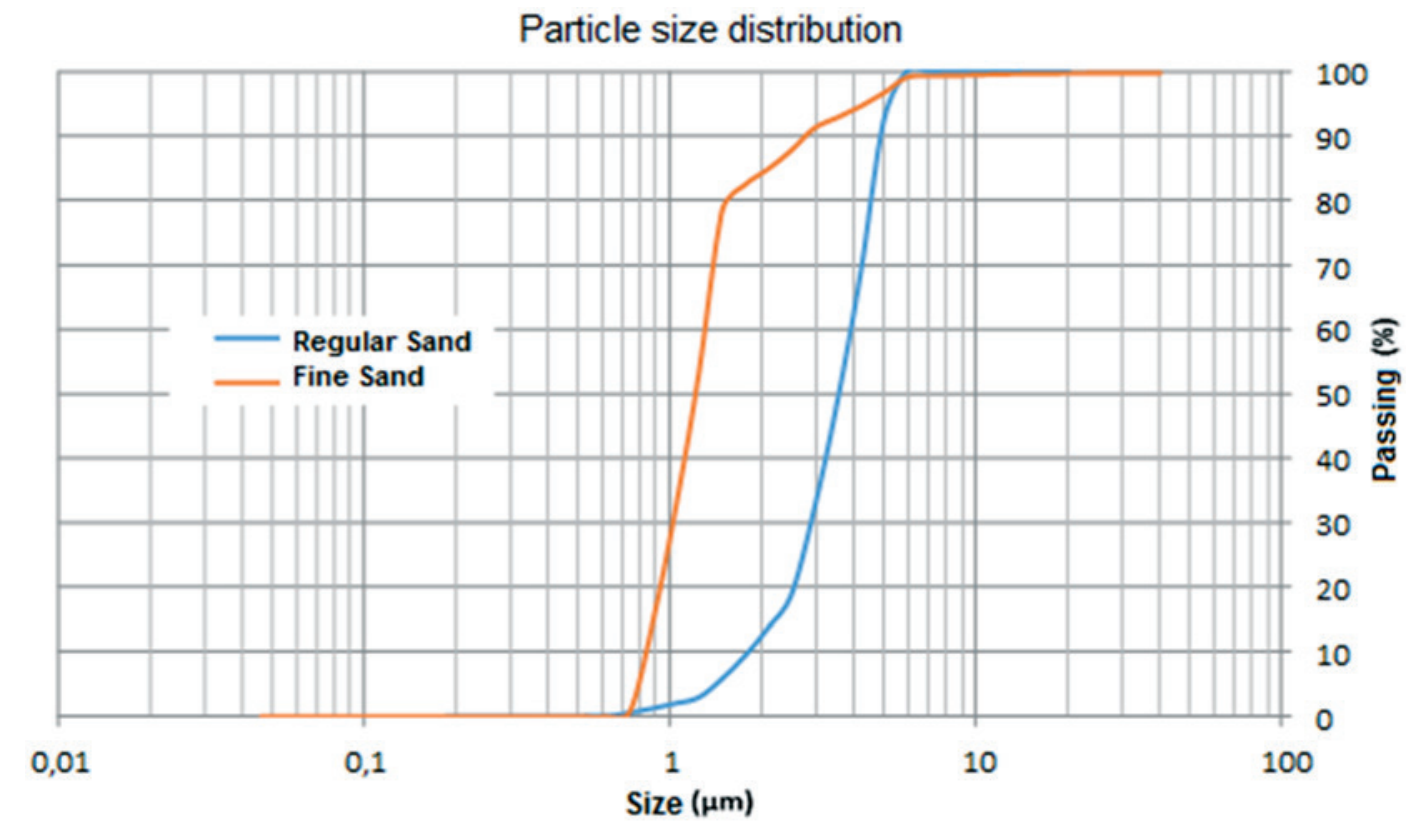

obtain the best packing possible, according to the Andreassen modified method.

Two types of fibers, steel and polypropylene, were used. The steel fibers have a length of $13 \mathrm{~mm}$ and a diameter of $0,21 \mathrm{~mm}$, with straight shape and tensile strength of $2750 \mathrm{~N} / \mathrm{mm}^{2}$. The polypropylene fibers are $6 \mathrm{~mm}$ long and $12 \mu \mathrm{m}$ in diameter. The polymer of this microfiber has a melting point of $160^{\circ} \mathrm{C}$ and $365^{\circ} \mathrm{C}$ ignition. Figure 3 shows steel and polypropylene fibers, which have shape coefficients of 0.01 and 0.0002 , respectively.

\subsection{Mix design and procedure}

The theoretical packaging method of Andreassen modified was used to obtain the proper mix design with the material's particle size distribution and the distribution coefficient "q" of 0.20 . This mix was previously developed with the advanced cementitious composite mix shown in Table 4, developed by Christ and Tutikian [17]. The specimens were fabricated using a single mixture in a vertical axis mixer with 5 -liter capacity during $18 \mathrm{~min}$. The still fresh material was subjected to a confining pressure of $20 \mathrm{MPa}$ for 24 hour with the aid of a special form.

After the stripping, specimens were subjected to a thermal curing at a temperature of $90^{\circ} \mathrm{C}$. 24 hours after, the samples were conditioned in a saturated humidity environment and controlled temperature of $21^{\circ} \mathrm{C} \pm 2$. To carry out the diagnose by image tests, no preparation or previous procedure was necessary. Tests for the mechanical's properties evaluation were carried out 28 days

\section{Figure 3 - Fibers used in the research}
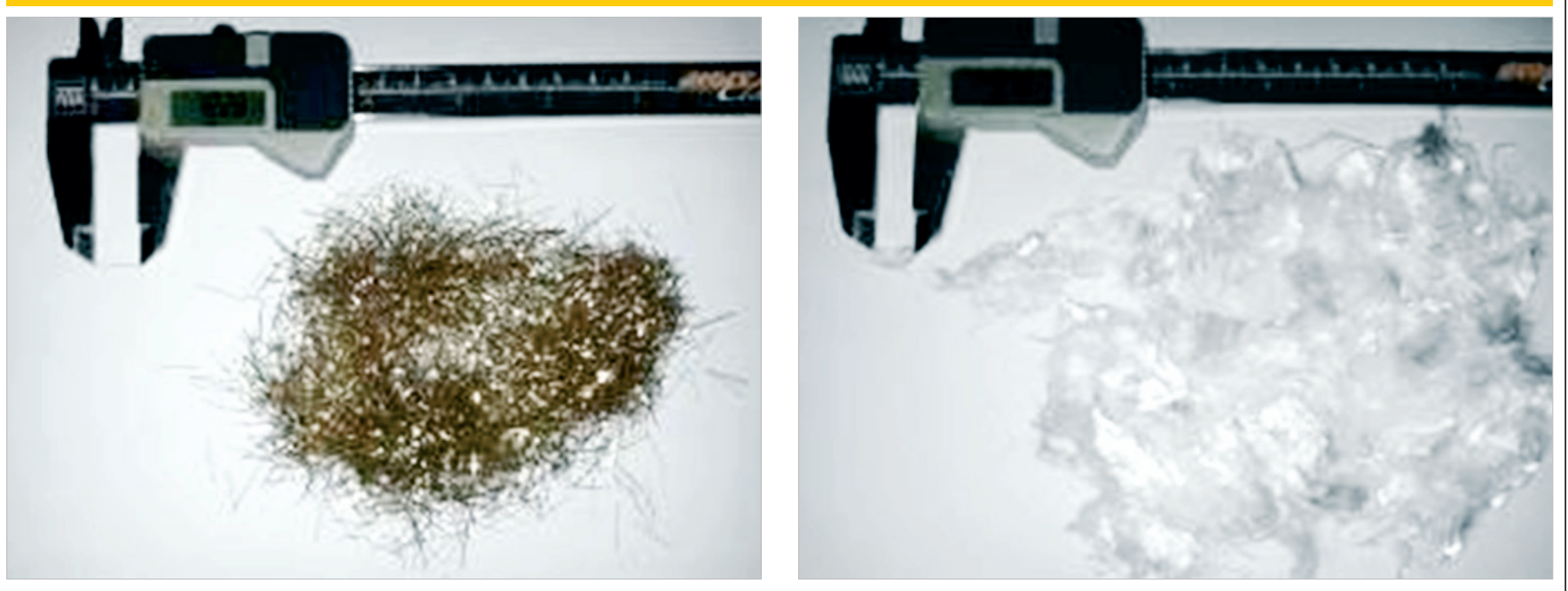
Table 4 - Mix proportion used in the production of advanced composite cementitious

\begin{tabular}{|c|c|c|c|c|}
\hline Materials & \multicolumn{2}{|c|}{ Unit mix } & \multicolumn{2}{|c|}{ Mix in $\mathrm{kg} / \mathrm{m}^{3}$} \\
\hline Cement & \multirow{3}{*}{1} & 0,44 & \multirow{3}{*}{573,59} & 251,80 \\
\hline Silica & & 0,37 & & 213,88 \\
\hline Fly ash & & 0,19 & & 107,91 \\
\hline Foundry sand & \multirow{3}{*}{2,39} & 1,02 & \multirow{3}{*}{1370,82} & 583,33 \\
\hline Fine sand & & 0,86 & & 495,83 \\
\hline Quartz powder & & 0,51 & & 291,66 \\
\hline Water & \multicolumn{2}{|c|}{$0,22^{*}$} & \multicolumn{2}{|c|}{126,19} \\
\hline Superplasticizer & \multicolumn{2}{|c|}{$0,03^{*}$} & \multicolumn{2}{|c|}{17,21} \\
\hline Viscosity modifier & \multicolumn{2}{|c|}{$0,01^{*}$} & \multicolumn{2}{|c|}{5,74} \\
\hline Steel fiber & \multicolumn{2}{|c|}{0,748} & \multicolumn{2}{|c|}{$188,4^{* *}$} \\
\hline Polypropylene fiber & \multicolumn{2}{|c|}{0,021} & \multicolumn{2}{|c|}{$5,46^{* *}$} \\
\hline
\end{tabular}

after its molding and have resulted in a compressive strength of $185 \mathrm{MPa}$ and in a bending tensile strength (4 points) of $44 \mathrm{MPa}$.

\subsection{D microtomography and SEM}

The 3D microtomography was performed at the Technological Institute in Functional Safety Testing, itt Fuse, in Unisinos University. The test was performed in the Laboratory of Electronics Characterization in a tomograph with $160 \mathrm{kV}$ cannon power and a maximum resolution of $0,5 \mu \mathrm{m}$, which performs $\mathrm{x}$-ray images of specimens with total volume of $1,0 \mathrm{~cm}^{3}$.

In order to obtain images, it was extracted a sample with $22 \mathrm{~mm}$ in diameter and $30 \mathrm{~mm}$ in height of a prismatic test specimen with $50 \mathrm{~mm}$ in diameter and $100 \mathrm{~mm}$ in height (Figure 4).

The images of the internal microstructure were captured from the same sample used for the $3 \mathrm{D}$ microtomography analysis. However, the sample was fragmented in a surface to enable the visualization of the fibers interaction with the composite. The analysis was also performed by SEM at the Technological Institute in Func- tional Safety Testing, itt Fuse, in Unisinos University. The equipment used is a SEM with EDS chemical analyzer, which allows the generation of images with resolution up to $3 \mathrm{~nm}$ with $700.000 \mathrm{x}$ magnification and $30 \mathrm{kV}$ of measurement energy and can operate in low and high vacuum. The test was performed in low and high vacuum, where the fibers' bonding was observed in low vacuum and the investigation of hydrated crystals existence was performed in high vacuum.

\section{Results and discussion}

\subsection{D microtomography}

Figure 5 shows the analyzed sample in its actual size. It is possible to observe that the density difference of the materials incorporated into the mixture is represented by the color difference. The cementitious matrix of the sample is displayed in green and the steel fibers in red, distributed throughout the sample. The polypropylene fibers have not been identified due to its low density. In order to

\section{Figure 4 - Sample used for the 3D microtomography analysis}
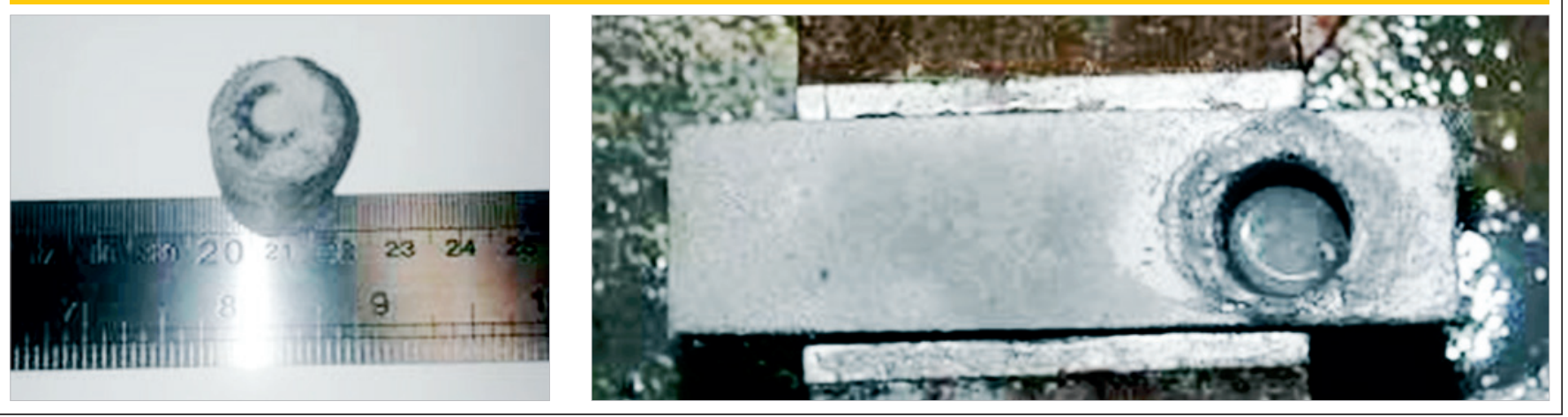


\section{Figure 5 - Peripheral view of the test specimen in 3D microtomography}

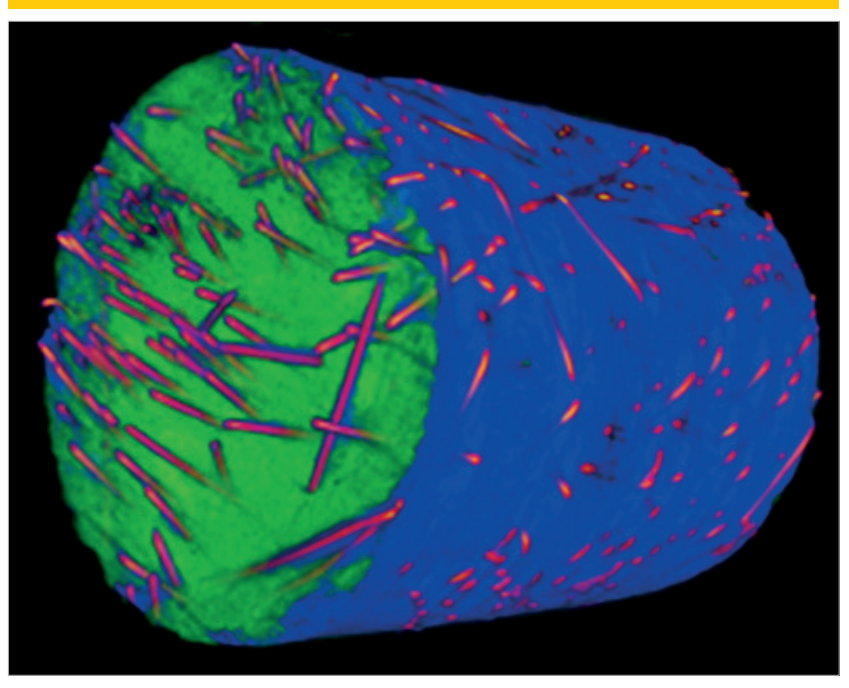

verify the steel fiber distribution, it was decided to generate a image with only these fibers, surface and a section of the specimen, as shown in Figure 6.

Analyzing Figure 06 (a) it is possible to observe the large concentration of fibers inserted into the mix, verified by the elements overlapping because the image capture angle. In Figure 06 (b) a section of the material was evaluated, avoiding the misinterpretation of fibers' distribution due to its overlap. Through this analysis, it can be noted that there are points in the mix where the fibers follow a parallel trend, but in almost all its entirety, the fibers form a mesh. It is also displayed a randomness arrangement of fibers in the element. Moreover, it is clear that the presence of polypropylene fibers, although not visible in the picture, did not segregate or influenced the distribution of steel fibers. Changing material's tone due to its density, sample's images were generated seeking to view polypropylene fibers' distribution, and these fibers were not displayed clearly, as shown in Figure 7.

Figure 8 was generated seeking a better preview of the set polypropylene fibers. This image shows that the steel fibers had a cut, which allows the verification of its position. It is possible to visualize the polypropylene fibers, but only with the interaction of all materials and, thus, the identification of these (shape, size and interaction) is compromised.

\subsection{Scanning Electron Microscopy (SEM)}

The SEM images produced show that the bonding of the fibers, both steel and polypropylene, with the cementitious matrix does not present faults or fragile zones at the interface. Figures 9 and 10 expose the connection of steel and polypropylene fibers, respectively.

As identified in Figure 9, the interface area between the steel fibers and the cementitious composite is not characterized by the presence of voids or gaps. Figure 10 shows fractures in the sample, which were derived from the cutting process. It is also possible to visualize the specimen's integrity in the region surrounding the fiber due to the lack of faults or breaking parts in its interface. Still using the SEM it was possible to visualize a sample stretch, which presents the distribution of the two fiber's type. Thus, it indicates the proportions of the dimensions of the two types of fibers incorporated in the mixture (Figure 11).

The dimension difference verified in Figure 11 allows the classification on a microscopic scale of steel fibers as macrofibers, while

\section{Figure 6 - Steel fiber's distribution full and partial view}

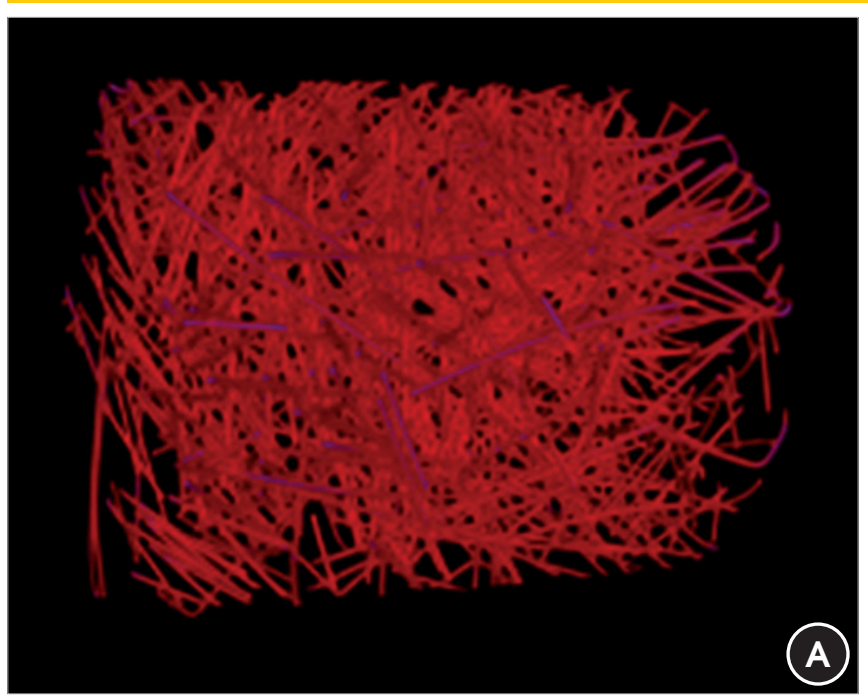

Total view

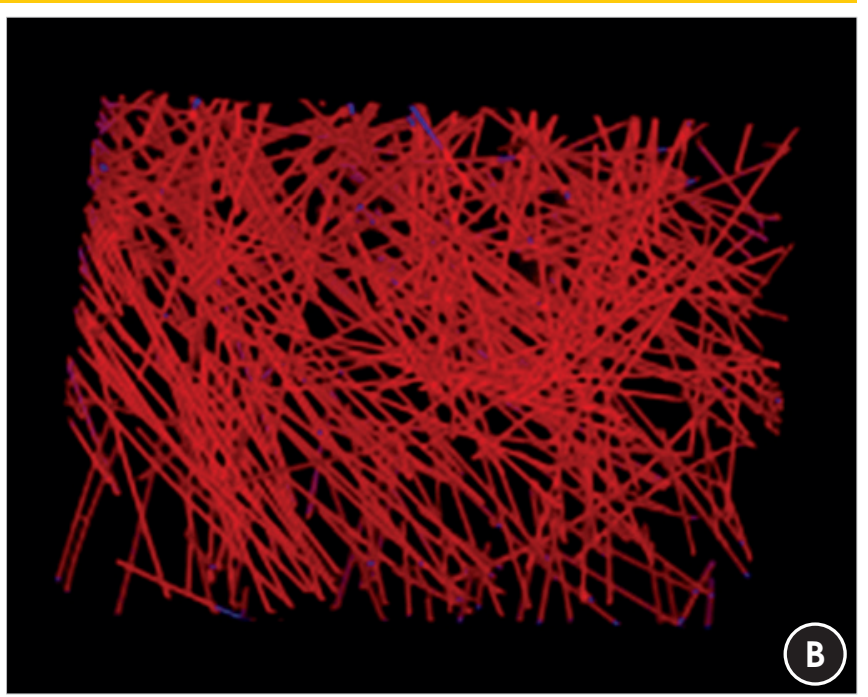

Partial view 
Figure 7 - 3D microtomography image for identification of low density material
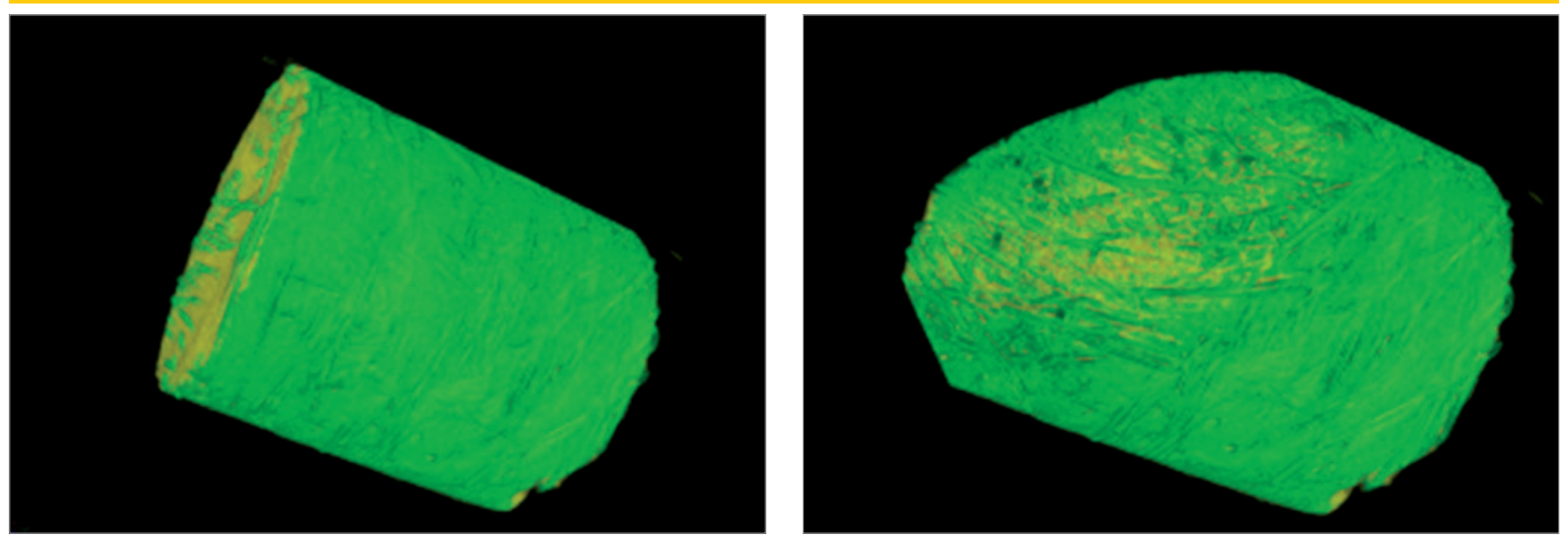

polypropylene fiber presents a microfiber function. Through this hybridization the microfibers causes the delay of microcracks while macrofibers act on post cracking step, preventing its extension. Therefore, there is no overlap in the function performed by any material and, in other hand there is a complementary behavior, which justifies the choice of fiber hybridity. Figure 12 shows the interface area between the cementitious composite and the steel fiber. This region generally presents fragility and generation of voids or paste lower density, nevertheless in the analyzed sample it was characterized by homogeneous density without hydrated crystals' identification.

The confining pressure applied after advanced cementitious com-

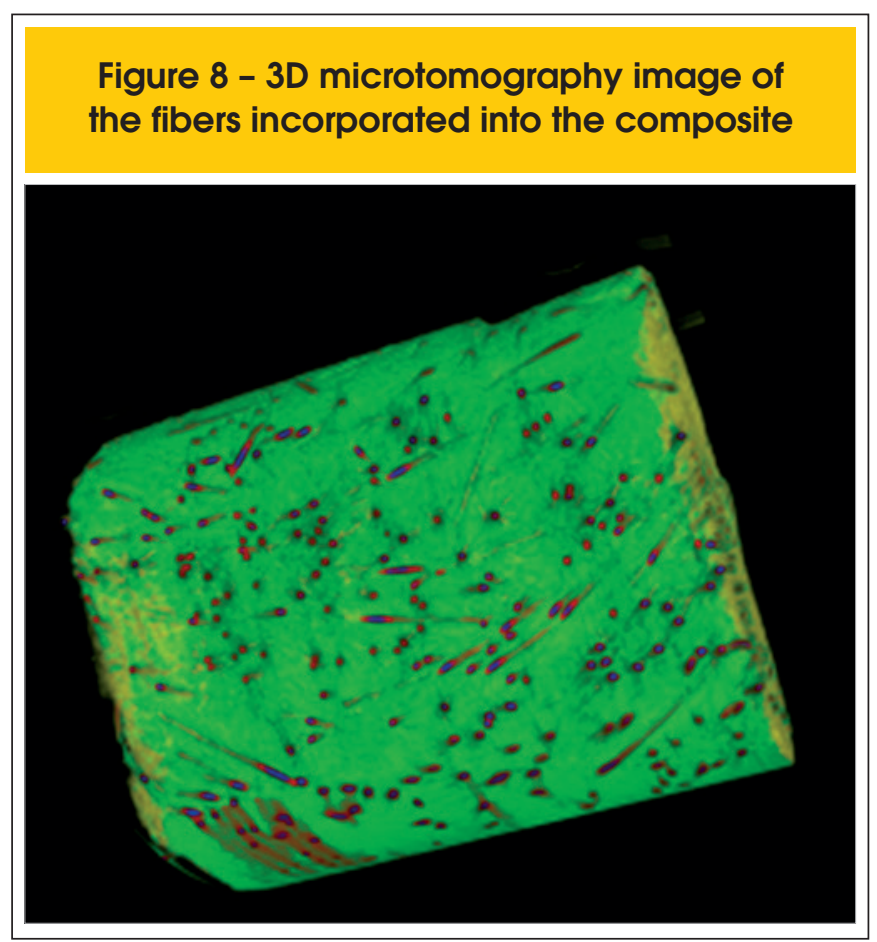

posites mixing still in the fresh state reduces its voids. Figure 13 shows the SEM obtained in the groove where a steel fiber was inserted and was withdrawn during specimen's cutting. It is possible to realize that the fiber was entirely wrapped by the cementitious composite.

This interface region is generally characterized by its fragility and the presence of voids or paste lower density. However, in the analyzed sample it was characterized by homogeneous density without the visualization of hydrated crystals, as mentioned before.

\section{Conclusions}

It was concluded that the diagnosis and evaluation of the composite occurred effectively with the use of $3 \mathrm{D}$ microtomography and scanning electron microscopy (SEM) techniques. 3D microtomog-

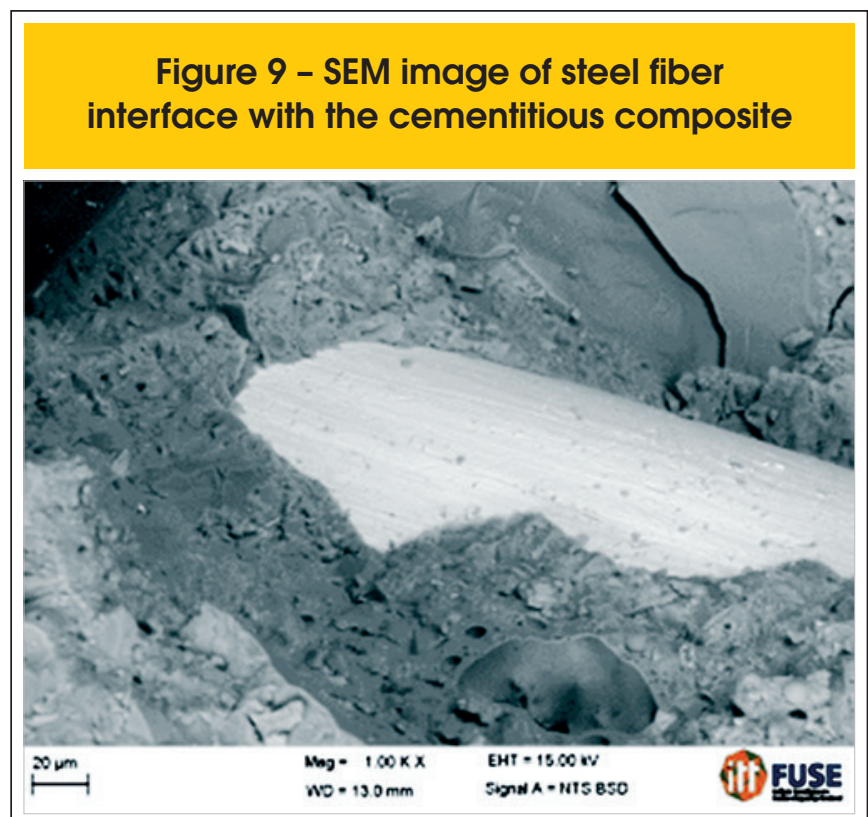




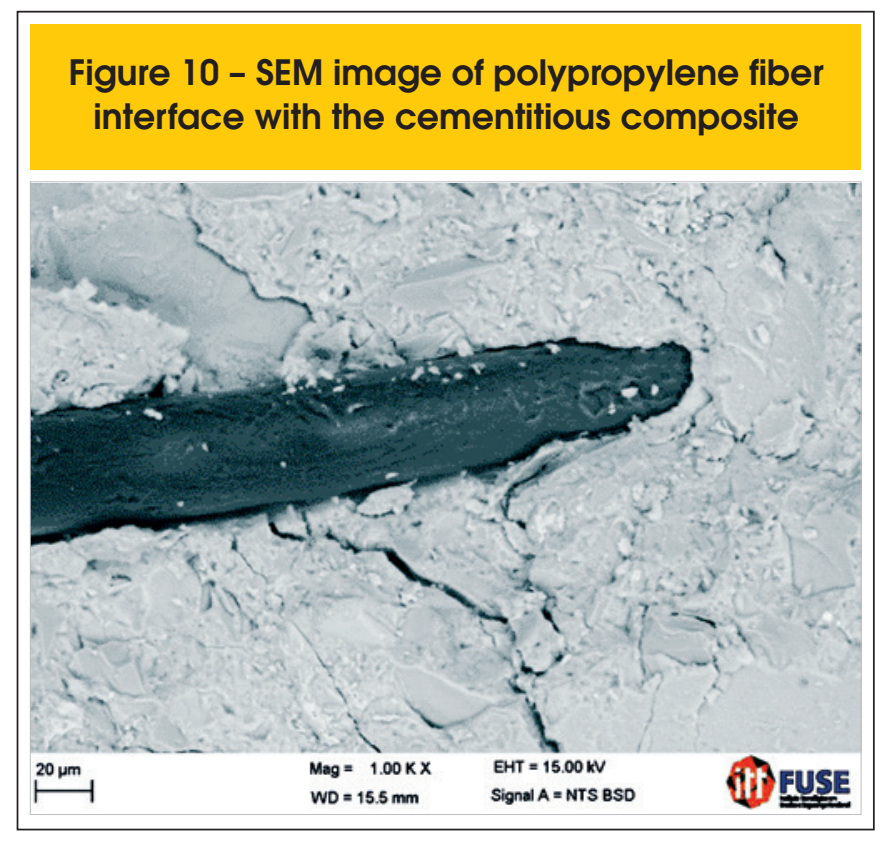

raphy allowed the visualization of steel fibers random distribution, with no failures in its distribution inside the matrix, even the heterogeneity between sample's core and its peripheral areas, indicating that there were no wall effects on molding or fiber inefficient distribution. However, the 3D microtomography did not allowed the identification of polypropylene fiber's distribution. Through SEM it was possible to analyze the interface between the fibers and the cementitious composite, verifying that it is not characterized as a fragile area or liable to the faults or damage occurrence. It is recommended to perform both tests for analysis and diagnosis of advanced cementitious composites.

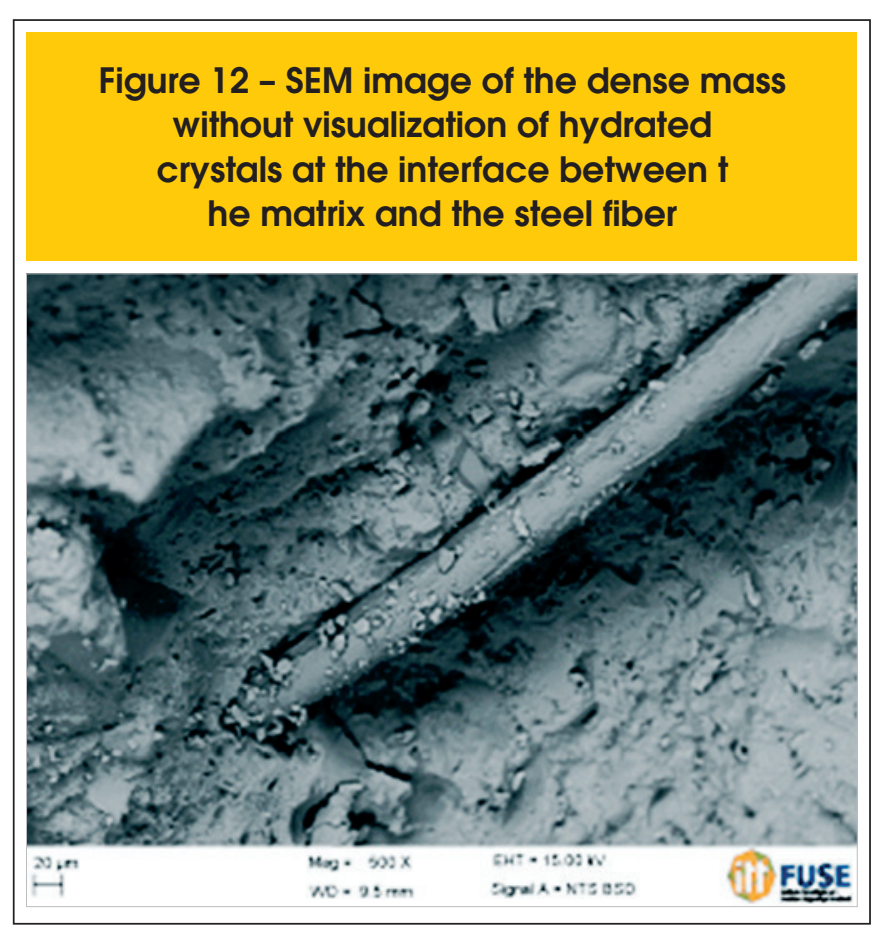

Figure 11 - SEM image of the distribution and geometry of the fibers in a sample stretch

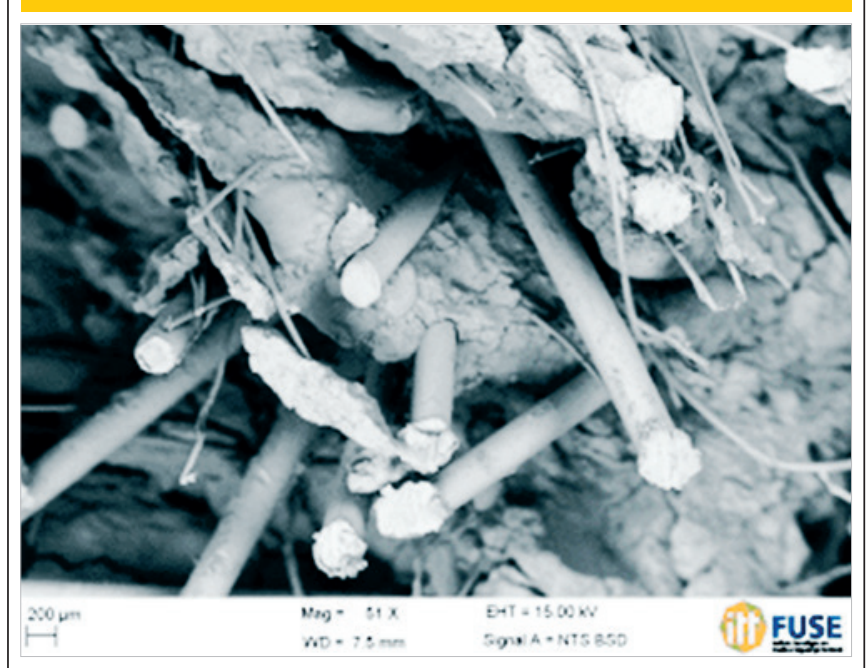

\section{Acknowledgments}

The authors wish to express their gratitude and sincere appreciation to itt Fuse - Technological Institute in Functional Safety Testing - Unisinos University and to itt Performance - Technological Institute in Civil Construction Performance - Unisinos University.

\section{References}

[1] LI, V. C. On Engineered Cementitious Composites (ECC)., (2003) Journal of Advanced Concrete Technology, v. 1, n. 3, p. 215-230.

[2] CALDARONE, M.A. (2009) High strength concrete - A practical guide. Taylor and Francis.

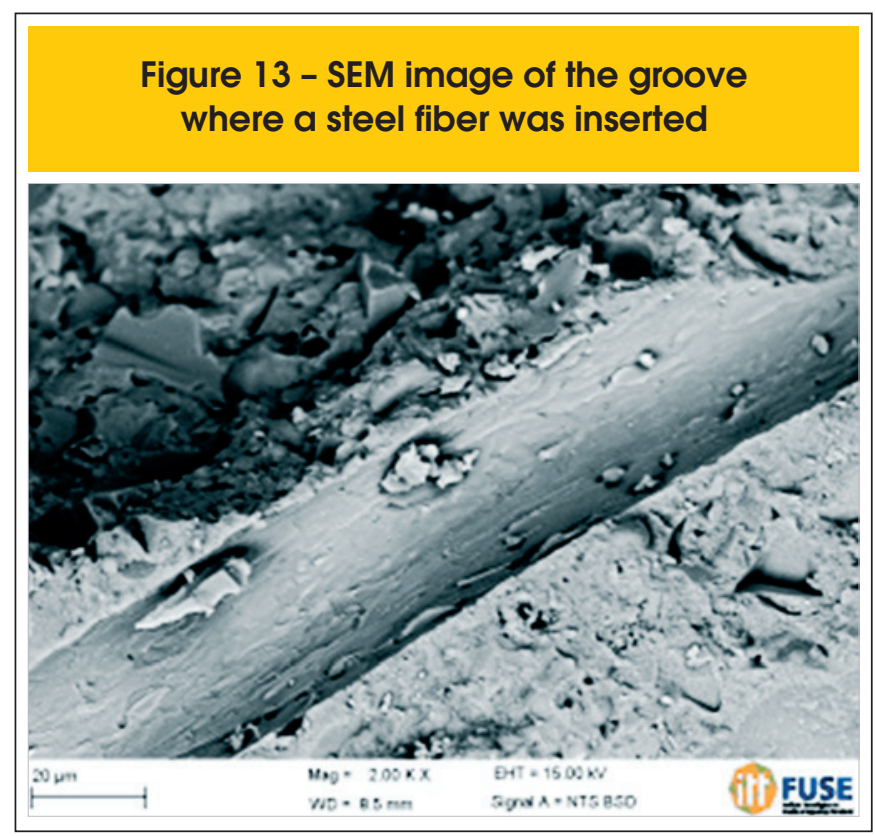


[3] BLAIS, P.Y, COUTURE, M. (1999). Precast, prestressed pedestrian bridge- World's first Reactive Powder Concrete Structure. PCl Journal.

[4] MARCOLIN, N. Criação no concreto (2006). Revista Pesquisa Fapesp, $\mathrm{n}^{\circ} 127$.

[5] NEVILLE, A.M; BROOKS, J.J. (2014) Concrete Technology. Trans-Atlantic Publications; 2nd Revised edition.

[6] DAWOOD, E. T.; RAMLI, M. Contribution of Hybrid Fibers on the Properties of High Strength Concrete Having High Workability. Procedia Engineering, jan. 2011. v. 14, p. 814-820.

[7] BANTHIA, N.; GUPTA, R. Hybrid fiber reinforced concrete (HyFRC): fiber synergy in high strength matrices. Materials and Structures, dez. 2004. v. 37, n. 10, p. 707-716.

[8] PIZZOL, V.D; MENDES, L.M; FREZATTI, L; SAVASTANO Jr, $\mathrm{H}$; TONOLI, G.H.D. Effect of accelerated carbonation on the microstructure and physical properties of hybrid fiber-cement composites. Minerals Engineering. Volume 59, January 2014, p. 101-106.

[9] PROMENTILLA, M.A.B (2011) MAB. Characterizing the microstructure of deteriorated cementitious materials with $\mathrm{x}$-ray microtomography. ASEAN Eng J 2011; 1. Online Referencing, http://www.seed-net.org/ASEANEJ_1-4.html (2013, accessado em 15 de dezembro de 2015.

[10] LANDIS, E.N; NAGY, E.N; KEANE, D.T; NAGY, G. Technique to measure $3 \mathrm{D}$ work-of-fracture of concrete in compression (1999) J. Eng. Mech. 125: 599-605.

[11] APPOLONI, C.R; FERNANDES, C.P; RODRIGUES, C.R.O. $X$-ray microtomography study of a sandstone reservoir rock. Nucl Instrum Meth A 580: 629-632.

[12] MACHADO, A. C; SILVA, M.A; FILHO, R.D.T; PFEIL, M.S; LIMA, I; LOPES, R.T.(2015) Investigação 3D da distribuição de fibras de aço em concreto reforçado por microtomografia de raios $X . R I E M, n^{\circ} 8$.

[13] ABDIN. Y. et al. Geometrical characterization and microstructural modeling of short steel fiber composites. Composites Manufacturing and Composites. Volume 67, December 2014, Pages 171-180.

[14] MAROLIYA, M.K (2012). Sustainability of ultra high strength reactive poder concrete. International journal of engineering research and development. Volume 4, Issue, 4, p 44-57.

[15] YAZICI, H; YIGITER, H; KARABULUT, A.S; BARADAN, B. (2008) Utilization of fly ash and ground granulated blast furnace slag as an alternative silica source in reactive powder concrete. Fuel, N87, p 2401-2407.

[16] HENRY, M; DARMA, I.V; SUGIYAMA, T. (2014) Analysis of the effect of heating and re-curing on the microstructure of high-strength concrete using X-ray $\mathrm{CT}$. Construction and building materials, 67, p37-46.

[17] CHRIST, R; TUTIKIAN, B. (2013) Study of pressure and curing temperature in Reactive Powder Concretes (RPC) with different amounts of Metallic Microfibers. Revista de la Construcción. Volumen 12-p 32-40. 